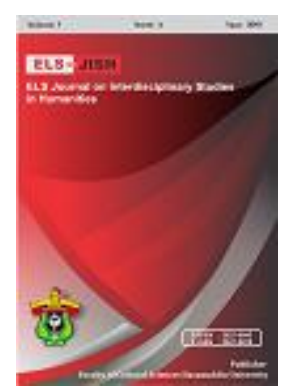

ELS-JISH

ELS Journal on Interdisciplinary Studies on Humanities

Volume 2 Issue 4, 2019

ISSN (print) : 2621-0843

ISSN (online) : 2621-0835

Homepage : http://journal.unhas.ac.id/index.php/jish

\title{
Hot Potatoes Multimedia Applications in Evaluation of Indonesian Learning in Junior High School Students in Buru District
}

\author{
Susiati ${ }^{1}$, Risman lye ${ }^{2}$, La Ode Achmad Suherman ${ }^{3}$ \\ 1 muhammadansori1809@gmail.com
}

\begin{abstract}
This study aimed to find out whether there is an influence of the Hot Potatoes multimedia application in evaluating junior high school students' learning outcomes in Indonesian language learning. The study design used an evaluation model with the multimedia application Hot Potatoes. The method used quantitative and qualitative description, which is to show the effect of evaluating student learning outcomes and student and teacher responses to the effectiveness of the use of multimedia Hot Potatoes. The data source of this research is the IX grade junior high school students in Buru Regency. Data collection techniques used in this study are test techniques using the multimedia application Hot Potatoes in the form of a Multiple-Choice Test (multiple-choice). The results showed that the application of the Hot Potatoes multimedia application in evaluating the learning outcomes of junior high school students in Indonesian language learning had a significant influence on quality learning. The influence can be seen from the results of the evaluation of 50 middle school students from cycle I, cycle II, and cycle III. The percentage of students completeness in cycle I was $60 \%$, cycle II was $86 \%$, and cycle III was $94 \%$. Meanwhile, the percentage of students completeness in the first cycle was $40 \%$, the second cycle was $14 \%$, and the third cycle was $6 \%$.
\end{abstract}

Keywords: Multimedia; Hot Potatoes; Learning Outcomes; Junior High

How to cite: Susiati, lye, R., \& Suheraman, L.O.A. (2019). Hot Potatoes Multimedia Applications in Evaluation of Indonesian Learning in Junior High School Students in Buru District. ELS Journal on Interdisciplinary Studies in Humanities, 2(4), 556-570

\section{Introduction}

Improving the quality of education is one of the most important elements in efforts to improve the quality of human resources, especially in the effectiveness og the teaching and learning process. The effectiveness in the teaching and learning process can be created if the instructor can utilize the learning methods that are suitable to the conditions of the students and the material that will be presented.

In the learning process, students often face problems internally and externally. One of the most common problems encountered is the teacher and learning infrastructure. The role of the teacher as a teacher as well as an educator is required to be able to design teaching materials that are effective and creative to evercome the difficulties experienced by students. Constitution No about Sisdiknas pasal 40

\footnotetext{
1, 2, Universitas Iqra Buru, Indonesia

${ }^{3}$ Universitas Muhammadiyah Buton, Indonesia
} 
states that "teachers and education personnel are obliged to create an educational atmosphere that is meaningful, fun, cretive, dynamic, and dialogic." (hlm. 98).

Nowadays the development of technology has been popular in the community, especially students, for example the use of mobile phones and laptops. This has resulted in changes in the mindset of students towards interest in learning. Nowadays students' interest in learning tends to like the pattern of games or quizzes. So, the application of learning design with multimedia-based models becomes one of the tactics in increasing students' level of understanding in each subject.

Very important thing to note is the problem of learning achievement. Many factors cause learning achievement to fail in the academic field both within students and students externally such as a low level of intelligence, lack of motivation to learn, ways of learning that are not effective, learning media or teaching materials that are still lacking by the school. The solution to the problem of learning achievement, namely by applying learning methods that are supported by technology. Multimedia technology has promised great potential in changing the way a person learns, obtains information, adjusts information, and so on.

Indonesian is one of the core subjects in the world of education that aims to be able to speak Indonesian well and correctly, skillfully in Indonesian. One alternative in expediting the teaching process is by utilizing information and communication technology or interactive multimedia.

Nowadays multimedia which is commonly known by the public is various kinds of combinations of graphics, text, sound, video, and animation. This integration is a unit that together displays information, messages or lesson content. Multimedia teaching materials are able to facilitate students who have visual, auditory, and kinesthetic learning styles so that all students can learn optimally (Arsyad, 2006).

Some of the facilities and infrastructure at every junior high school in Buru Regency are already very supportive based on interviews and observations that have been carried out. Some schools are already equipped with computer laboratories. The tendency of teachers to teach in the classroom with the lecture method and not yet use facilities and infrastructure as much as possible. Students want to get teaching that is more interesting and not boring.

Based on the description above, this study aims to determine whether there is an influence of the application of Hot Potatoes multimedia with the evaluation of junior high school student learning outcomes in Indonesian language learning.

\section{Literature Reveiew}

\subsection{Multimedia Concepts}

Diartono (2008) in the American dictionary defined that multimedia is a combination of the use of several media such as films, slides, music, lighting with text, images, especially for educational purposes (p. 54). Multimedia is a combination of data, sound, video, audio, animation, graphics, text and sounds which a combination of these elements can be exposed through a computer (Lencien, 1998).

A computer that can use video clips, sound recordings, images, animations and text and can also control devices such as video recorders, video disc players, CDROOM boosters, and video cameras (Simon, 1995). 
So, it can be concluded that multimedia is a technique or a modern model in the field of computers that combines more than one media in a form of communication that includes text, sound, graphics, animation, and video into a computer system.

\subsection{Use of Multimedia in Learning}

The experts recommend that in implementing the learning process the teacher should use complete media, according to the needs and touch various senses. Many advantages of multimedia-based learning when compared to whiteboard and chalk. Almost all sense elements are involved in multimedia-based learning.

Mayer (2001) said that overall, multimedia consists of three levels, namely (1) the technical level is multimedia related to technical tools. These tools can be interpreted as a vehicle that includes signs (signs); (2) semiotic level, namely the representation of multimedia results such as text, images, graphics, tables, etc .; (3) sensory level, which is related to the sensory channel that functions to receive signs (p. 78). By utilizing the three levels above, it is hoped that we can optimize multimedia and get effective use of multimedia in the learning process.

\subsection{Hot Potatoes}

The Hot Potatoes display revealed several pictures of potatoes. A brief history of the emergence of Hot Potatoes is from the word "Hot" which means "Hot" and "Potatoes" meaning "Potatoes". This Hot Potatoes Software was made by Victoria University in Canada. Educational institutions in Indonesia have freely used this software. This application was created as a tool to explore questions so that the display of questions is not monotonous. Hot Potatoes are often referred to as a question bank-making tool. This is because this application focuses on becoming a learning medium for making questions. Hot Potatoes consists of six programs that can be used to create interactive and web-based teaching materials and questions (Amir, Siswaningsih, \& Hana, 2013).

Similarly, Nurwanti et al (2015) stated that Hot Potatoes is a program that can be used to make exam questions or digital-based questions. The operation allows students to learn without difficulty, because each question has a clue answer and the answer key provided. Hot potatoes function as interactive relationships, repetition, feedback and rewards (p. 26).

\subsection{Hot Potatoes Program for Teaching Indonesian}

Hot Potatoes can be said as a learning media if the contents meet the learning elements that can meet the instructional objectives of each material and questions contained in this software. Thus, all elements in learning can be achieved with the media Hot Potatoes (Subari, 2008).

Baso (2005) states that this software can be used freely by educational institutions. The homepage of this software is http://www.halfbakedsoftware.com This hot potatoes software homepage is Version 6. 


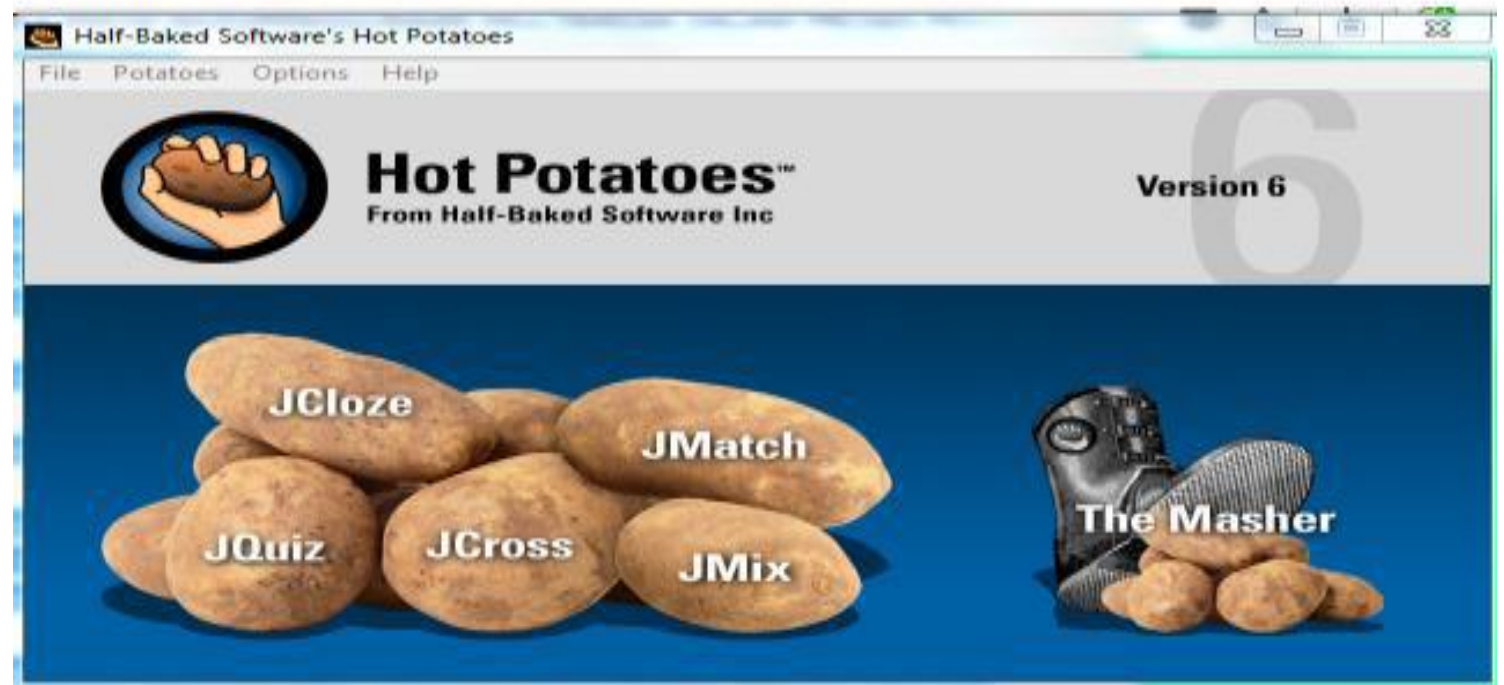

Figure 1. Home Hot Potatoes (Source: http://1.bp.blogspot.com)

The five programs contained in this software, are: (1) JQuiz: (2) Jmix; (3) Jcross; (4) Jmatch; (5) Jcloze (p. 69)

\subsection{The Use of the Hot Potatoes Program}

The program contained in this software has the following format 1) creating and writing material; 2) design the output configuration; 3) save the master; 4) export files or save files in a web document (html). In making evaluation Questions with Hot Potatoes Program can be seen from these following steps:

How to make a multiple choice question (Multipple Choice) with Hot Potatoes:

a. Activate the Hot Potatoes program

b. Tap the icon that says Jquiz

c. Tap in the title box and write the name of the exercise (choose one exercise)

d. Write your question in the question box

e. In the answer box, answer box, write possible answers sequentially from A, B, $\mathrm{C}, \mathrm{D}$, and so on and give the correct answer in the box provided.

f. Write feedback for each answer, whether correct or wrong. This feedback is very useful to direct users to recognize their answers.

g. The next question can be made by pressing / clicking on the up arrow located to the left of the question number.

h. Enter the desired question.

i. The questions that have been made can be configured by clicking the "Options" menu and then selecting "Configure Output".

1) This option will display a new dialog box with several options, including:

2) Titles / Instruction; to configure or change the shape and type of the title.

3) Prompt / Feedback; prepare feedback facilities (responses) that will be displayed. 
4) Buttons; can be used to create hyperlinks to the next quiz or to other pages on the web.

5) Appearance; This facility is prepared to change the appearance of the quiz, for example by changing the color display.

6) Save data at the desired location. As on your PC / laptop hard disk or on other external (flash, CD, and diskette).

7) The data or file can be exported to HTML or in web format by clicking on the spider's web button icon located on the wrong tool bar. This makes your data or files stored in the form of a web page.

Khikmawati (2014) states that the advantages of using the Hot Potatoes application, including 1) are more efficient in terms of energy and time; 2) cost efficient because it is not necessary to print questions if an evaluation of learning outcomes is carried out so that printing costs can be allocated to other learning activities; 3) the questions done between one student and another have a different arrangement, because the questions are usually randomized by the test maker software; 4) For multiple choice questions, right and wrong can be directly assessed by software; 5) Allows for the integration of images, sound, video into evaluation questions, so that it is hoped that it can help students understand the purpose of the problem (p. 78).

There are five programs contained in the Hot Potatoes software, in this study one model will be taken, namely Jquiz (a program for preparing multiple choice training material). The following are the stages of displaying Jquiz evaluation questions using the multimedia hot potatoes program in Indonesian language learning in grade IX.

\section{a. Opening Page Views}

The opening page display is displayed first when the learning media application starts. It looks, that is, a closed wooden fence. To open it, click the "Open" button. The following is the appearance of the opening page.

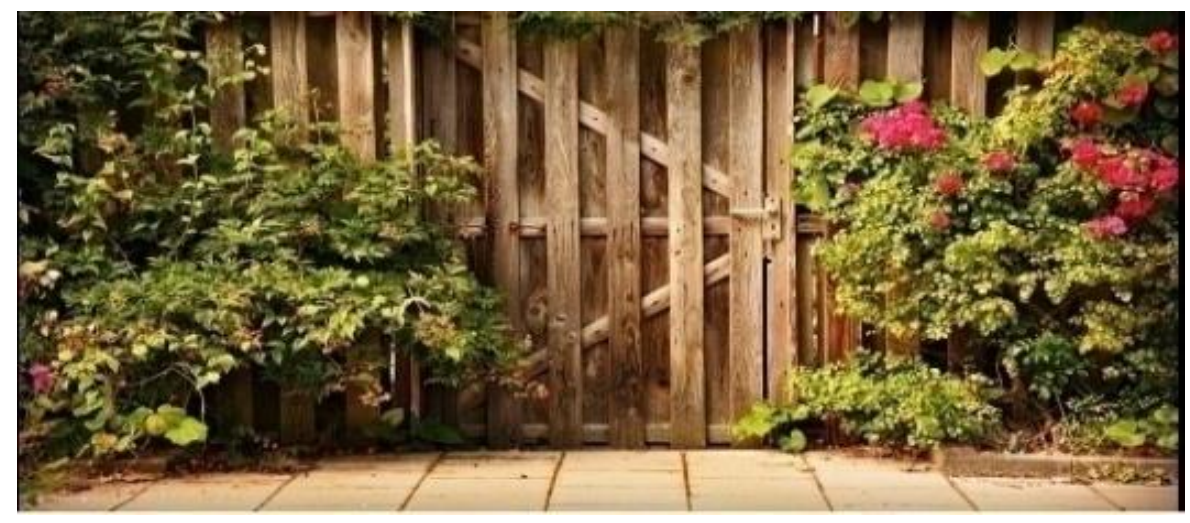

Figure 2. Opening Page Views (Source: Private photo gallery)

The display above is the first display of the hot potatoes application, it will automatically sound an audio command to press the gate on the screen.

b. Display Page Introduction 
The introductory page display will open automatically after the gate is pressed. This display also includes audio that contains the command sentence! The following is the introductory page display image.

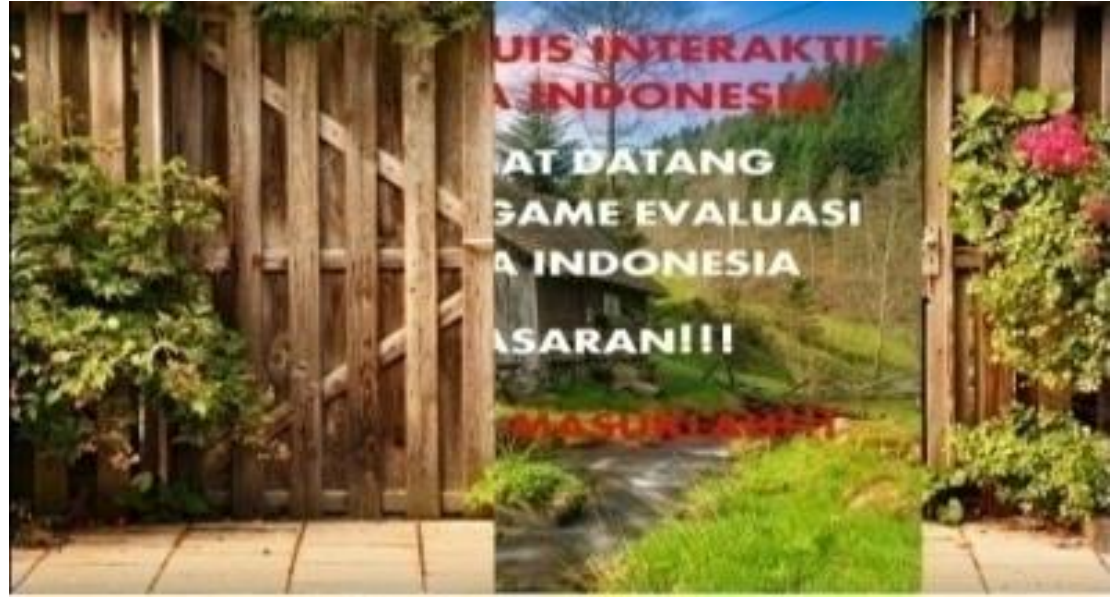

Figure 3. Display Page Introduction (Source: Private photo gallery)

The introductory page contains persuasive statements. It is intended that students can be motivated and challenged to demonstrate their ability to work on the Indonesian language problems presented. The following is an introductory page view.

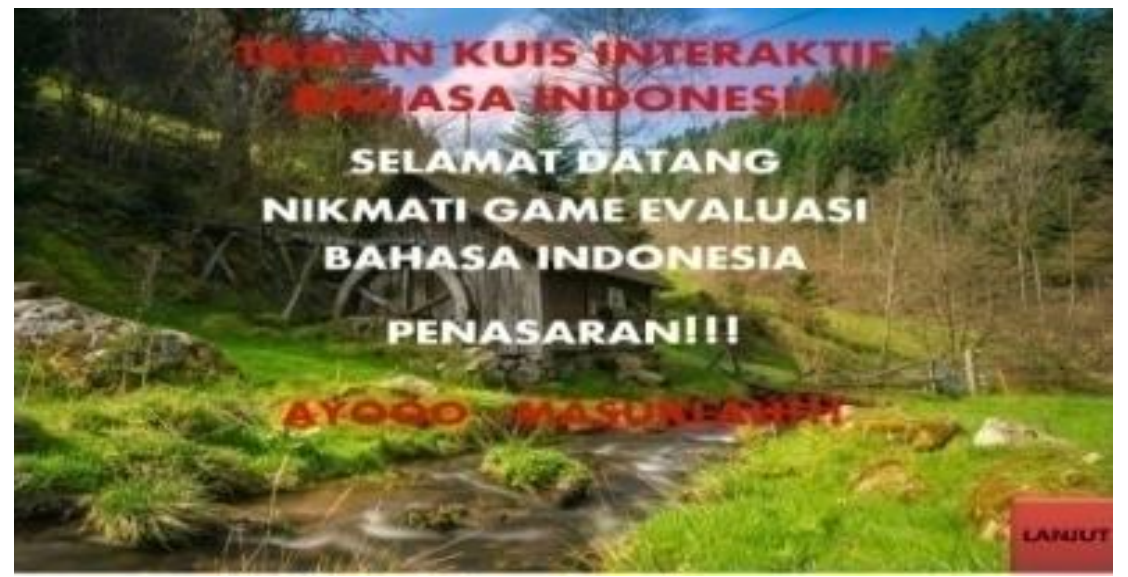

Figure 4. Display Page Introduction (Source: Private photo gallery)

\section{c. Trial Tutorial Page Views}

The evaluation tutorial page display is displayed when clicking the "continue" button on the introductory page view. The evaluation tutorial page contains some evaluation questions that will be done by students provided time allocation for each question and answer key. To open each evaluation question, click each "evaluation" column. The following are the evaluation page 1 views, evaluation 2, evaluation 3. 


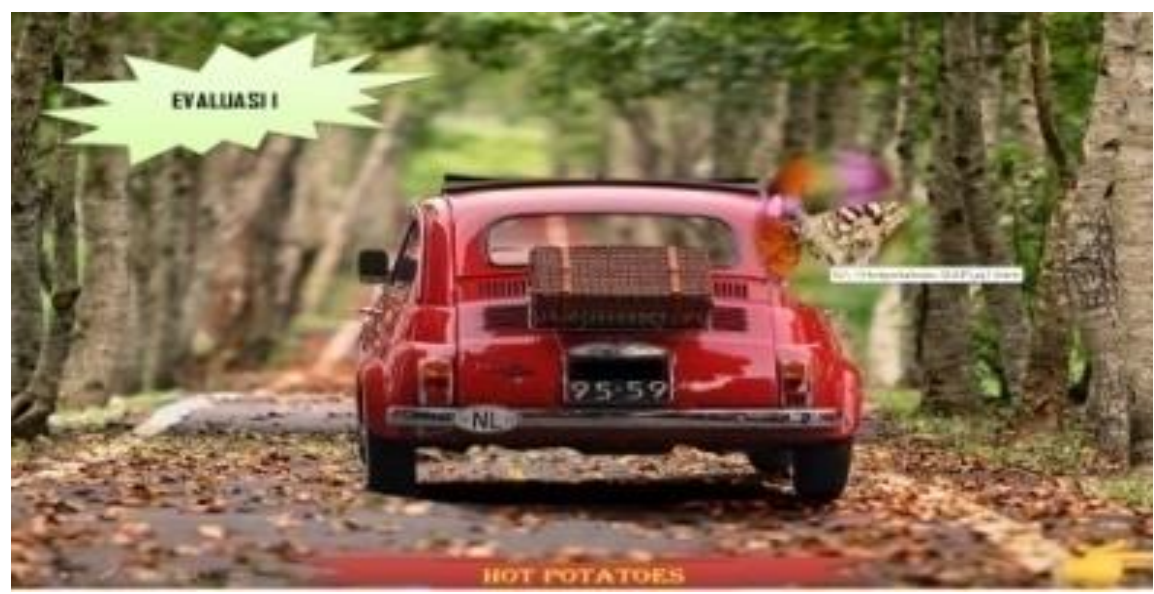

Figure 5. Trial Tutorial Page Views (Source: Private photo gallery)

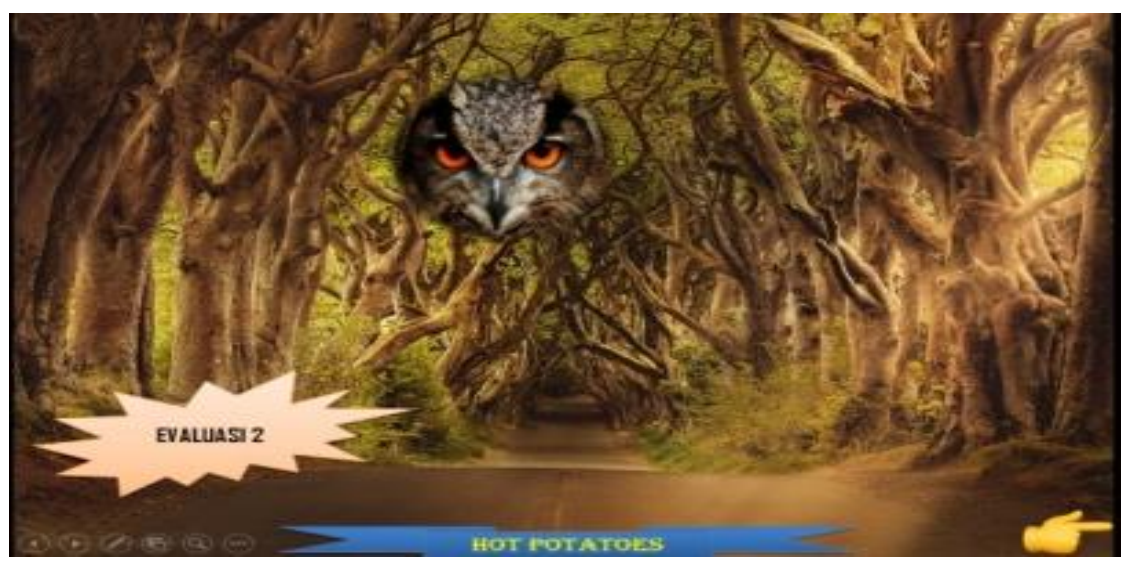

Figure 6. Display of the First Trial Tutorial (Source: Private photo gallery)

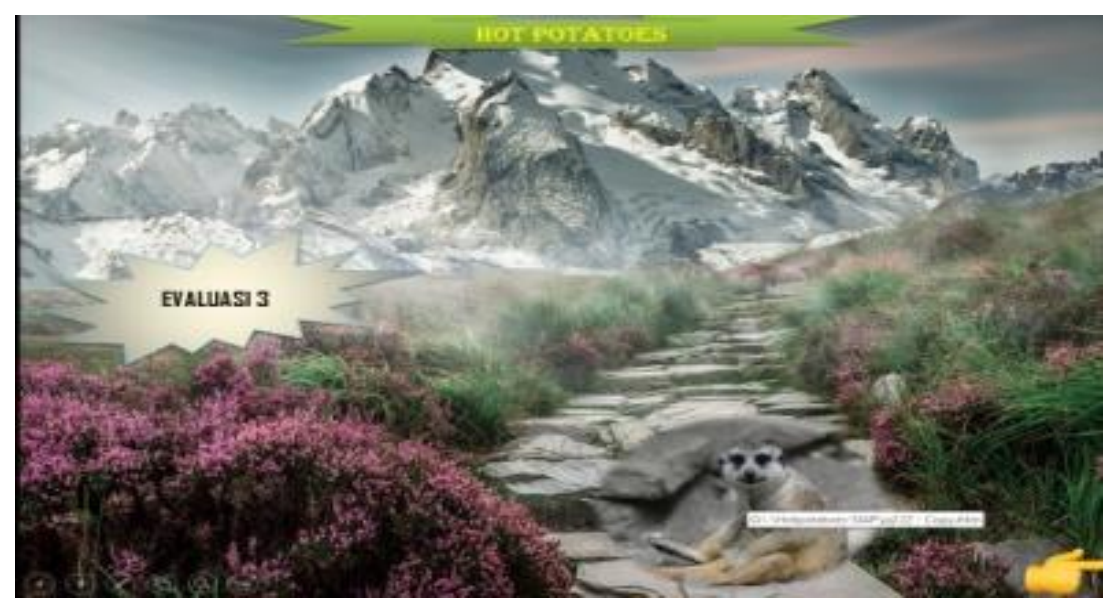

Figure 7. Display of the Second Trial Tutorial (Source: Private photo gallery)

Some of the pictures above are a display of evaluation stages. The evaluation phase in this application consists of five evaluation stages. However, only three of these articles are displayed, i.e. Figure 1 is the evaluation stage I, to enter the evaluation problem please press the butterfly image, it will automatically open and display the evaluation question. In picture 2 is the evaluation phase 2 , to enter the evaluation questions please press the owl picture. Figure 3 for the evaluation stage 
3 , to enter the evaluation question, please press the ferret picture. The number of questions per evaluation is 50 numbers.

\section{d. Display of Problem Pages}

The three images below are the evaluation page views. Evaluation questions total 50 numbers at each evaluation stage.

The problem is accompanied by a moving animation. If the student answers incorrectly, an animated image will automatically cry or sad. Conversely, if students answer correctly they will automatically appear a happy thumb and cartoon image.

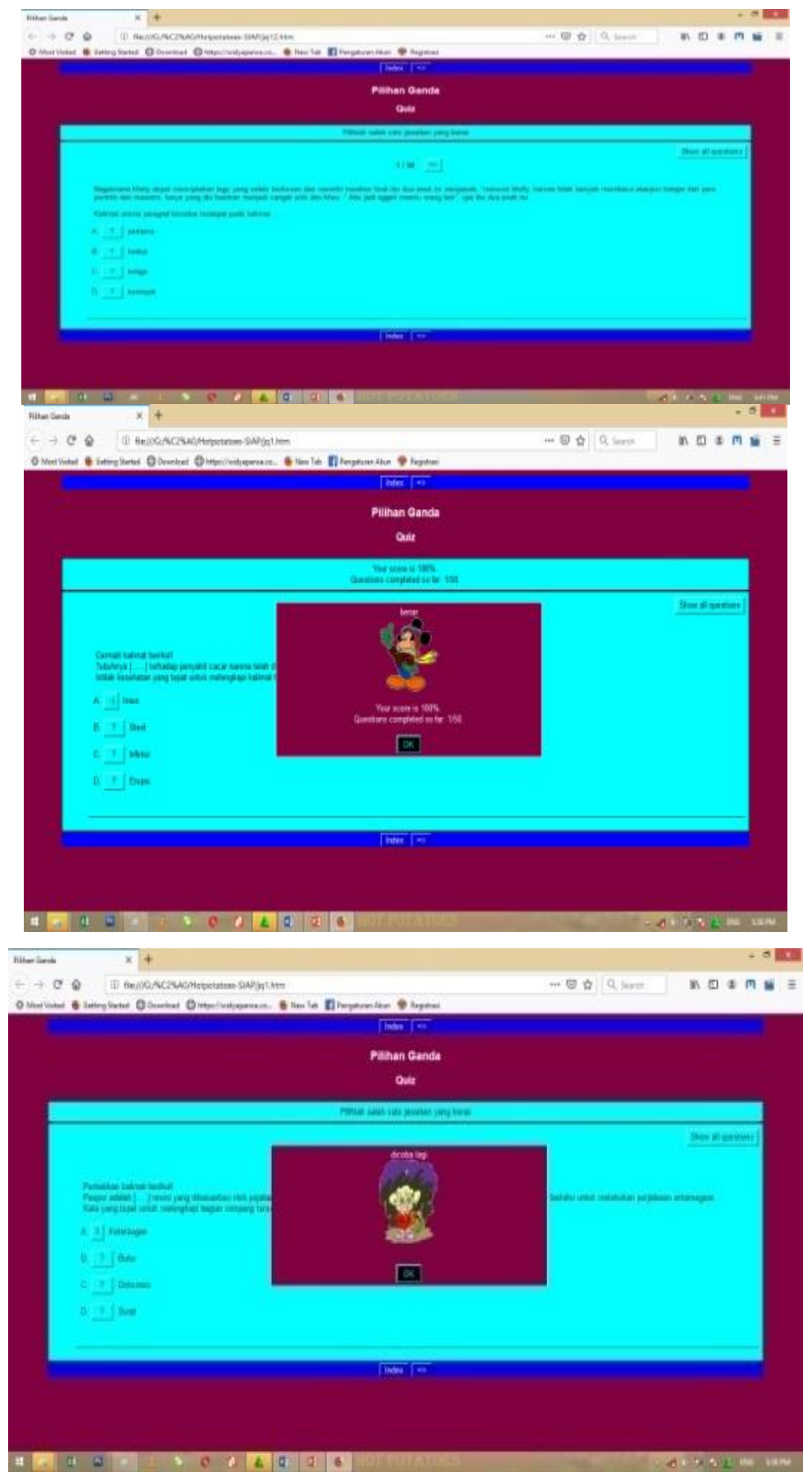

Figure 8. Display of Problem Pages (Source: Private photo gallery) 
e. Cover Page Display
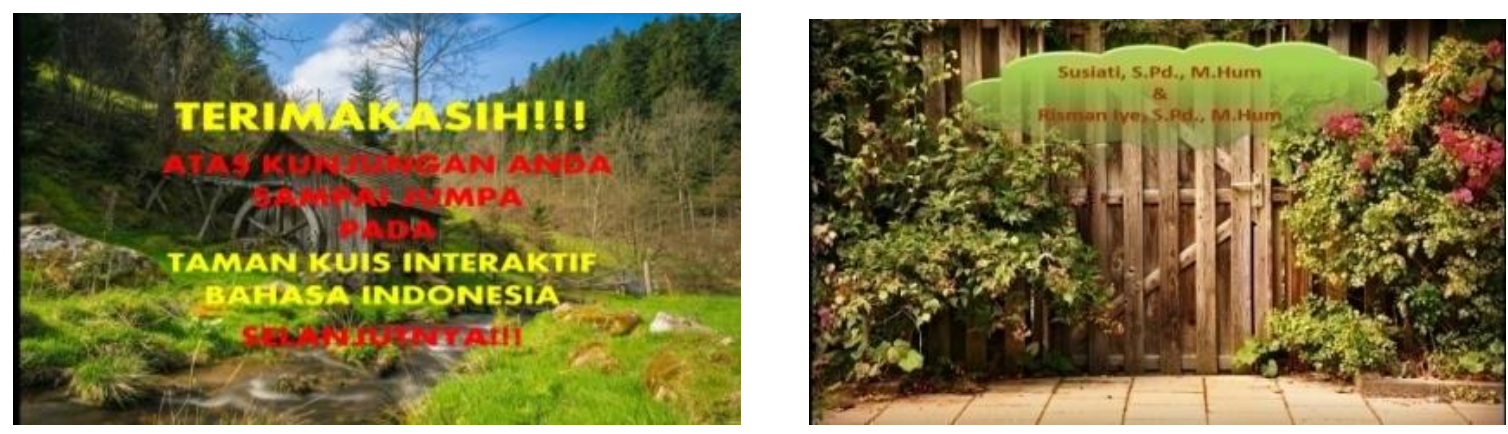

Figure 9. Cover Page Display (Source: Private photo gallery)

\section{Research Method}

The research and development method (Research and Development) is the method chosen in this research. Research and development methods are products that test the effectiveness of a product.

According to Borg and Gall (1989), the model of educational research and development (Educational Research and Development) that can be used is a system approach model designed by Walter Dick and Lou Carey. The steps of implementing MPI research and development according to Suparman (2012), namely: (1) identifying instructional needs and writing general instructional objectives (TIU); (2) conducting instructional analysis; (3) identify the behavior and initial characteristics of students; (4) Writing Specific Instructional Purpose (ICT); (5) developing learning outcomes assessment tools; (6) developing instructional strategies; (7) developing instructional materials; (8) draw up designs and carry out formative evaluations; (9) instructional system; (10) Implementation, Innovation Innovation, and Sumartif Evaluation (p. 75).

\subsection{Data collection technique}

Data collection techniques used in this study were test techniques. This type of test is used to collect data about the level of learning outcomes of Indonesian language through evaluation using the Hot Potatoes multimedia application in the form of a multiple-choice test. Evaluation activities are carried out in three cycles. Before these cycles are carried out the teacher will provide an explanation of Indonesian language material that refers to the National Exam material grid. The activities, including first the students will be evaluated using the student worksheet media until the third cycle. Each cycle number of questions by 50 numbers so that the total number of questions until the third cycle of 150 numbers. Second, students will be evaluated using the multimedia hot potato application until the third cycle. The questions for each cycle are the same as the questions for each student evaluation cycle using the student worksheet media. The difference lies in the evaluation media.

In this study the Multiple Choice Test was chosen to be an evaluation test because the application of the Hot Potatoes multimedia learning model is expected to improve the ability and understanding of student training in preparation for the UN (National Examination). 


\subsection{Data Sources and Types}

The data source of this research is the IX grade junior high school students in Buru Regency. The number of data sources was determined by 10 students and 1 educator per school. The number of SMP schools to be investigated is 5 SMP, namely SMP 1 Buru, SMP Negeri 2 Buru, SMP Negeri 9 Buru, SMP Negeri 11 Buru, SMP Negeri 14 Buru. Thus, there are 50 junior high students and 5 teaching staff.

\section{Results and Discussion}

\subsection{Main Heading of the Analysis or Results}

The implementation of the development of multimedia hot potatoes in evaluating Indonesian learning is carried out in class IX at 5 (five) SMPNs in Buru Regency, including Buru 1 Junior High School, Namlea 2 Middle School, 9 Buru Middle School, 11 Buru Middle School, 14 Buru Middle School . Evaluation activities are carried out in three cycles. Before these cycles are carried out the teacher will provide an explanation of Indonesian language material that refers to the National Exam material grid.

The activities, including first the students will be evaluated using the student worksheet media until the third cycle. Each cycle number of questions as many as 50 numbers so that the total number of questions to the third cycle of 150 numbers. Second, students will be evaluated using the multimedia hot potato application until the third cycle. The questions for each cycle are the same as the questions for each student evaluation cycle using the student worksheet media. The difference lies in the evaluation media.

\subsection{Student Evaluation Results Using Student Worksheet Media}

Student worksheet media is a matter of using paper media typed using a computer or typewriter. In each test, students were evaluated using media in the form of student worksheets with a multiple choice model with a number of questions as many as fifty numbers.

Based on the results of the calculation of test data obtained information that completeness achieved by class IX students of the five high schools totaling fifty people is $10 \%$ or stated $90 \%$ of students declared incomplete. This is influenced by the monotonous Indonesian question model and makes students tired of reading so that it affects the selection of answers that are less thorough. The visual appearance of a problem can affect the students' interest in working on the problem carefully and in focus. Technological developments have greatly influenced students to enable learning or evaluation activities using digital applications, such as Hot Potatoes, are better implemented. This can be seen from the cycles below.

\section{Cycle I}

Based on the results of the calculation of test data obtained information that the completeness achieved by students of class IX of the five public high schools totaling fifty people is still low, namely: 
Table 1. Average Student Evaluation Results in the first cycle test

\begin{tabular}{cccc}
\hline Criteria & $\begin{array}{c}\text { The number of } \\
\text { students }\end{array}$ & information & Average value \\
\hline $\begin{array}{l}\text { Students who work } \\
\text { on problems 100\% }\end{array}$ & 15 people & Complete & 72 \\
\hline $\begin{array}{l}\text { Students who work } \\
\text { on problems 100\% }\end{array}$ & 35 people & Not complete & 43 \\
\hline
\end{tabular}

From the results of the evaluation, the answers of students in cycle 1 can be seen that the majority of students received a very low grade, which is the average value of 43 obtained by students who numbered 35 people. They are classified on an incomplete scale. Meanwhile, an average score of 72 was obtained by students with a total of 15 people. They are classified as complete scale.

From the results of the final test in the first cycle it can be concluded that the students have not been maximized in working on Indonesian language evaluation questions using media in the form of student worksheets.

\section{Cycle II}

Based on the results of the calculation of the final test data in the second cycle obtained information that the completeness of class IX students of the five public high schools, which numbered fifty people belong to the low scale, but the number of students who completed increased and the acquisition of the average value also increased. Here is the table.

Table 2. Average Student Evaluation Results in the second cycle test

\begin{tabular}{cccc}
\hline \multicolumn{1}{c}{ Criteria } & $\begin{array}{c}\text { The number of } \\
\text { students }\end{array}$ & information & Average value \\
\hline $\begin{array}{l}\text { Students who work } \\
\text { on problems 100\% }\end{array}$ & 18 people & Complete & 75 \\
\hline $\begin{array}{l}\text { Students who work } \\
\text { on problems 100\% }\end{array}$ & 32 people & Not complete & 45 \\
\hline
\end{tabular}

From the results of the evaluation, the answers of students in the second cycle of the test can be seen that the majority of students received a slightly significant value from the first cycle of the test, which is incompletely reduced by 3 people to 32 that have not been completed with an increase in value which is also significant, namely the average score average 45 . Meanwhile, students who complete numbered 18 people with an average value of 75 .

\section{Cycle III}

Based on the results of the calculation of the final test data in the third cycle obtained information that the completeness of class IX students of the five public high schools totaling fifty people still belong to the low scale, namely

Table 3. Average Evaluation Results of Students in the test cycle III

\begin{tabular}{cccc}
\hline Criteria & $\begin{array}{c}\text { The number of } \\
\text { students }\end{array}$ & information & Average value \\
\hline $\begin{array}{c}\text { Students who work on } \\
\text { problems } 100 \%\end{array}$ & 23 people & Complete & 75 \\
\hline $\begin{array}{c}\text { Students who work on } \\
\text { problems } 100 \%\end{array}$ & 27 people & $\begin{array}{c}\text { Not } \\
\text { complete }\end{array}$ & 47 \\
\hline
\end{tabular}


From the evaluation results, the answers of students in the third cycle can be seen that the majority of students received a slightly significant value from the second cycle, ie those who did not complete reduced by 5 people to become 27 unfinished with an increase in value which was also significant, namely an average value of 47 Meanwhile, students who completed were 23 people with an average grade of 75 equal to the second cycle.

\subsection{Student Evaluation Results After Using Multimedia Evaluation of Hot Potatoes}

In the test, students are evaluated using the media in the form of multimedia Hot Potatoes multiple choice with a number of questions as many as fifty numbers. The questions are the same as the questions on the student worksheet on.

Based on the results of the calculation of the data in the test obtained information that completeness achieved by class IX students of the five high schools totaling fifty people was $95 \%$ or stated $5 \%$ of students declared incomplete. This is influenced by the Indonesian language problem model by using multimedia hot potatoes which leads to the needs of students now that their visuals are already attached to technology for example students are interested in thematic, pictorial, feedback, and interactive problem models. This is very influential on the selection of the right answer. The visual appearance of a problem can affect the students' interest in working on the problem carefully and in focus. Technological developments have greatly influenced students so that learning or evaluation activities using digital applications, such as hot potatoes, really help attract students to focus on working on the problems.

\section{Cycle I}

Overall the average percentage of student acquisition in the evaluation of cycle I using the multimedia hot potatoes application is presented in table 5 .

Table 4. Average Evaluation Results of Students in Cycle I

\begin{tabular}{cccc}
\hline Criteria & $\begin{array}{c}\text { The number } \\
\text { of students }\end{array}$ & information & Average value \\
\hline $\begin{array}{l}\text { Students who work } \\
\text { on problems 100\% }\end{array}$ & 30 people & Complete & 75 \\
\hline $\begin{array}{l}\text { Students who work } \\
\text { on problems 100\% }\end{array}$ & 20 people & Not complete & 48 \\
\hline
\end{tabular}

From table 4 above it can be explained that the development of multimedia hot potatoes in evaluating Indonesian learning is in the medium position. This can be seen from the fifty students who took the test 20 people who did not complete with the acquisition of an average value of 48 and 30 people who completed the acquisition of an average value of 75 . The percentage of students completeness in the first cycle was $60 \%$ and the percentage of incompleteness students in the first cycle are $40 \%$.

The effect of the application of evaluation using multimedia hot potatoes is very interesting for students because in the evaluation product the first display focuses on the visuality of students, namely the display of images or animation so that students are very interested. With this, it has very positive implications when students enter the evaluation stage slide, which is displaying multiple choice questions. 


\section{Cycle II}

Based on the results of the calculation of the data on the final test in the second cycle obtained information that the completeness of class IX students of the five public high schools totaling fifty people belonged to a high scale, with the number of students completing increasing and the acquisition of average scores also increasing in the complete and static categories in incomplete category. Here is the table.

Table 5. Average Student Evaluation Results in Cycle II

\begin{tabular}{llll}
\hline \multicolumn{1}{c}{ Criteria } & $\begin{array}{c}\text { The number of } \\
\text { students }\end{array}$ & information & Average value \\
\hline $\begin{array}{l}\text { Students who work on } \\
\text { problems 100\% }\end{array}$ & 43 people & Complete & 80 \\
\hline $\begin{array}{l}\text { Students who work on } \\
\text { problems 100\% }\end{array}$ & 7 people & Not complete & 50 \\
\hline
\end{tabular}

From the results of the evaluation, the answers of students in the second cycle can be seen that the majority of students received a high score, ie an average score of 80 obtained by students totaling 43 people. They are classified as complete scale. Meanwhile, an average score of 50 was obtained by students with a total of 7 people. They are classified on an incomplete scale. The percentage of students completeness in cycle II was $86 \%$ and the percentage of students completeness in cycle II was $14 \%$.

From the final results of the test in the second cycle it can be concluded that the students are very maximal and focused in working on Indonesian evaluation questions using the media application of hot potatoes.

\section{Cycle III}

Based on the results of data calculations at the end of the third cycle test obtained information that the completeness of class IX students of the five public high schools totaling fifty people belonged to a very high scale, with the number of students completing increasing and the acquisition of average scores also increasing in the complete and static categories on incomplete category. Here is the table.

Table 6. Average Student Evaluation Results in Cycle II

\begin{tabular}{cccc}
\hline Criteria & $\begin{array}{c}\text { The number of } \\
\text { students }\end{array}$ & information & Average value \\
\hline $\begin{array}{c}\text { Students who } \\
\text { work on problems } \\
100 \%\end{array}$ & $\begin{array}{c}47 \\
\text { People }\end{array}$ & Complete & 85 \\
\hline $\begin{array}{c}\text { Students who } \\
\text { work on problems } \\
100 \%\end{array}$ & 3 people & Not complete & 58 \\
\hline
\end{tabular}

From the results of the evaluation, the answers of students in the third cycle can be seen that the majority of students received a high score, ie an average score of 85 obtained by students totaling 47 people. They are classified as complete scale. Meanwhile, an average score of 58 was obtained by students in the number of 3 people. They are classified on an incomplete scale. The percentage of students 
completeness in cycle III is $94 \%$ and the percentage of students completeness in cycle III is $6 \%$.

From the final test results in the third cycle, it can be concluded that the students were very maximal and focused in working on Indonesian evaluation questions using the Hot Potatoes application media.

Judging from the results of the test the students when following the Indonesian evaluation using the worksheet media students are on a low scale. This can be seen from the results of cycles I, II, and III, while the results of the students' evaluation tests when participating in the evaluation with the application of multimedia hot potatoes are on a very high scale. This can be seen from the results of cycles I, II, and III.

From these results it can be concluded that the development of multimedia hot potatoes in evaluating Indonesian learning really helps students' interest and focus in working on the problem and eliminates boredom, lazy reading students towards a reading.

\section{Conclusion}

Based on the results of the research in the previous discussion, it can be concluded that a number of findings in this study related to the influence of the Hot Potatoes multimedia application in evaluating junior high school student learning outcomes in Indonesian language learning. One alternative to smoothing the teaching process is to apply a multimedia-based learning model. That is, because of the low student learning outcomes caused by the lack of application of the method of compiling evaluation questions which are fun. Evaluation is included in the learning component needed in education. The results showed that the application of the Hot Potatoes multimedia application in evaluating the learning outcomes of junior high school students in Indonesian language learning had a major influence on quality learning. This can be seen from the results of the evaluation of 50 middle school students from cycle I, cycle II, and cycle III. The percentage of students completeness in cycle I was $60 \%$, cycle II was $86 \%$, and cycle III was $94 \%$. Meanwhile, the percentage of students completeness in the first cycle was $40 \%$, second cycle was $14 \%$, and third cycle was $6 \%$.

\section{Acknowledgments}

Acknowledgments to Kemenristekdikti which has given the authors confidence in conducting research through Penelitian Dosen Pemula. The author also thanks the Region XII Higher Education Service Institution (LL Dikti), Universitas Iqra Buru, and the ELS-JISH Journal for providing assistance in completing this research until the end.

\section{References}

Amir, E., Siswaningsih, W., \& Hana, M. N. (2013). Pengembangan Web Assesment dengan Hot Potatoes pada Materi Reaksi Oksidasi dan Reduksi. Jurnal Riset Dan Praktik Pendidikan Kimia.

Arsyad, A. (2006). Media Pembelajaran. Jakarta: PT. Rajagrafindo Persada.

Baso, Y. S. (2005). Teknik Dasar Penggunaan Multimedia dalam Pengajaran Bahasa Arab. 
Jurnal Nady Al-Adab, 1(1), 67-69.

Borg, W. R., \& Gall, M. D. (1989). Educational Research: An Introduction (5th ed.). New York: Longman.

Diartono, D. A. (2008). Media Pembelajaran Desain Grafis Menggunakan Photoshop Berbasis Multimedia. Jurnal Teknologi Informasi DINAMIK, 8(2).

Khikmawati, M. N. (2014). Perangkat Lunak Untuk Tes Berbasis Perangkat Elektronik.

Lencien, T. (1998). Le Multimèdia. Paris: Clè International.

Mayer, R. E. (2001). Aids to Computer-Based Multimedia Learning. USA: Departemen Psikologi, University of California.

Nurwanti, M., \& Al, E. (2015). Penerapan Model Instructional Games Menggunakan Hot Potatoes Untuk Meningkatkan Penguasaan Konsep Siswa Pada Materi Ekosistem. BioEduIN, 5(1), 23-34.

Simon, C. (1995). Multimedia Systems, Multi-media. Oxford: Made Simple Books.

Subari. (2008). Penggunaan Hot Potatoes Dalam Pembelajaran (E-Learning). In Workshop Program PHK Inherent, 51. Malang: Universitas Islam Malang.

Suparman, M. A. (2012). Desain Instruksional Modern: Panduan Para Pengajar dan Inovator Pendidikan. Jakarta: Erlangga. 